UDC 502.5+502.064.2

K.A. Vasyutinska, PhD, Assoc. Prof., S.V. Barbashev, DSc, Prof.

Odessa National Polytechnic University, 1 Shevchenko Ave., Odessa, Ukraine, 65044; e-mail: ekaterina.vasutinskaya@gmail.com

\title{
THE ANALYSIS OF THE PRINCIPLES AND METHODS EVALUATION OF ENVIRONMENTAL SAFETY LEVELS IN REGIONAL CONTEXT
}

\begin{abstract}
К.А. Васютинська, С.В. Барбашев. Аналіз принципів і методів оцінювання рівнів екологічної безпеки в регіональному pозрізі. Диференціація регіонів України за відповідними індикаторами та рівнями екологічної безпеки $\epsilon$ фундаментом для розроблення національної стратегії та організації ефективних безпекових заходів. Визначення пріоритетів та аналіз методичних основ оцінювання і диференціації територіальних утворень за рівнями екологічної небезпеки є метою роботи. Концептуальна та методологічна основа оцінки, аналізу та прогнозу рівнів небезпеки територій: методи інтегральної оцінки, методи оцінювання ризику, метод нормованих показників, метод вагових коефіцієнтів в мультиплікативній та адитивній формі, кластерний метод. Узагальнені принципи та методи оцінювання стану природно-техногенної безпеки території. Проаналізовано основні підходи до ранжування регіонів України за рівнями екологічних небезпек чи асоційованих 3 ними екологічних ризиків. Запропоновано критерії оцінювання екологічної ситуації неоднорідних за функціональним призначенням та масштабами територіальних утворень. Обговорено причини значного коливання рейтингів областей за рівнями безпеки та запропоновані шляхи подолання протиріч в методології їх ранжування. Обгрунтоване введення індексу «урбогенності» регіону та врахування відновлювальних можливостей природних ландшафтів як основи стабілізації екологічної рівноваги та компенсації негативних техногенно-урбогенних впливів. Для диференціації областей запропонований кластерний метод, який може враховувати складність геосистем, адаптивну поведінку компонентів, однотипність екологічних ситуацій в регіонах - членах однієї групи.

Ключові слова: екологічна безпека, рівень небезпеки, екологічний ризик, комплексний екологічний індикатор,
\end{abstract} регіони України

K.A. Vasyutinska, S.V Barbashev. The analysis of the principles and methods evaluation of environmental safety levels in regional context. Comparison of regions of Ukraine according to relevant indicators and levels of environmental safety is the basis for developing a national strategy and organizing effective safety measures. The aim to determine priorities and to analyze the methodological bases of evaluation and differentiation of territorial areas according to the levels of environmental hazard. Conceptual and methodological basis for the assessment, analysis and forecasting of hazard levels of territories: integrated assessment methods, method of standardized indicators, risk assessment methods, weighting coefficient method in multiplicative and additive form, cluster method. The principles and methods for assessing the state of natural and man-made safety of the territory are generalized. The main approaches to ranking the regions of Ukraine for the levels of environmental hazards or environmental risks associated with them had analyzed. The approaches and criteria for assessing the ecological situation of heterogeneous in terms of functional purpose and scale of areas are proposed. We have discussed the reasons for a significant fluctuation of safety ratings of the regions and ways to overcome the methodological limitations of their definition. We have substantiated the introduction of the index of "urbogenicity" of the region, and considering the restorative possibilities of natural landscapes as the basis for stabilizing the ecological balance and compensating of negative man-made and urban influences. The clustering method that can consider the complexity of geosystems, the adaptive behavior of components, the sameness of ecological situation in the region as members of one group, were proposed to differentiate regions.

Keywords: ecological safety, hazard level, ecological risk, total environmental indicator, regions of Ukraine

Introduction. The center of the concept of national security of Ukraine is the security of a person, whose survival is associated with the preservation of the environment. Therefore, human security is realized through the provision of natural and man-made safety of the territory of its residence. The degree of aggregation and functionality areas where the population lives, can vary greatly - from small settlements to cities, regions and the whole country. But any taxonomic unit is a complex, specific natural-territorial geosystem with a dynamic structure, characterized by interactions of man-made, natural and natural-man-made components. All groups of factors have a cumulative effect on man and landscapes, which from the very beginning are formed in the conditions of these influences and, at the same time, reflect the degree of their transformation, deformation and disturbances. Thus, the levels of ecological safety correspond to the necessary stages of reproduction of the geosystem, the conditions for preserving the ecological balance of the natural territory as its foundation.

DOI: .

(C) 2017 The Authors. This is an open access article under the CC BY license (http://creativecommons.org/licenses/by/4.0/). 
A wide range of urbanized territories of Ukraine, the versatility of their use, the diversity of landscape, climatic, environmental conditions and features requires the principles of research and comparison that take into account simultaneous factors of homogeneity and differentiation. This is due to complex and multi-level natural and man-made phenomena and factors that, when interacting in different types of territories, form different environmental situations. Ranging procedures for territories of different levels - from individual urban agglomerations to regions of Ukraine - require reliable criteria for comparing diverse factors. Hence the need to develop common approaches that would allow simultaneously to consider the state of the ecological danger of any territories, small cities and metropolises, regions and their various functional areas. The differentiation of the territory according to the environmental situation and the levels of environmental safety most corresponds to the system concept of ensuring human safety and is the basis for the implementation of safety measures.

The basis of the organization of a complex of measures to achieve sustainable safety of the territory is the assessment, analysis and forecast of indicators of the ecological state. Environmental indicators are an integral part of the system of indicators of national safety of Ukraine, although they are insufficiently used at the current level.

The concept of global environmental indicators considers indicators of constancy and indices of quantitative content of components of the ecological, economic, social component. The indicators proposed by international organizations [1] include:

1) Living Planet Index;

2) Indicators "Ecological Footprint” and "Water Footprint”;

3) Environmental Sustainability Index, proposed by the Yale and Columbia Universities of the USA;

4) UN system of indicators "Millennium Development Goals”;

5) UN system of indicators “Adjusted Net Savings”, etc.

All indicators, by their nature, reflect two opposing approaches - eco-centered and anthropocentric. Thus, the Index of Ecological Sustainability (3), as well as the indicators (4) and (5), belong to the second group, because they take into account population growth, technical and economic development. Indicators (1) and (2) relate to the provision of biodiversity, reserves of natural capital, assimilation capabilities of natural systems, which allows them to be belong to group 1 .

These indicators take into account the man-caused, natural-climatic and resource factors of the impact on the level of environmental safety, which is considered through the prism of preserving the ecological balance and sustainability to anthropogenic pressure. Along with the indicators of ecodesign impact on the system of indicators, social and economic indicators [2] are included, which allows to take into account the effectiveness of environmental activities through the inclusion of financing indicators (environmental taxes, charges for resource use), energy efficiency indicators, indicators of implementation of environmental projects, etc. Such an approach to the development of the system of indicators more fully corresponds to the concept of sustainable development and allows us to assess the state of the ecological safety of any region on its basis.

Materials and methods. Ranking for signs of tension ecological situation, ecological condition, the degree of environmental hazards is carried out using complex indicators of danger [3-5] or environmental risks [6, 7]. Approaches that are the foundations of existing models differ on the basis of the calculation of the index evaluation. Analytical methods can be based on standardization or normalization of indicators and determining the size of the deviation from the average, or in determining the weight coefficients. The application of weight coefficients can be in additive or multiplicative form (Table 1).

Presented in Table 1 methods are characterized by certain limitations. Thus, in the case of an integral assessment, the valuation of indicators leads to an overlimit of excessive influences. Subjectivity of the method of weighting coefficients consists in their determination by the expert estimation method.

Evaluations of the ecological safety of the territory in all its multiplicity reflect the main areas of human life - socio-economic development, use and condition of human potential, ecological state of the environment. Therefore, the indicators used include natural, man-made and social groups of fac- 
tors, the number and selection of which may affect the results of the analysis, and their volume can be quite significant.

Table 1

Methods of calculating ecological hazard indices

\begin{tabular}{|c|c|c|}
\hline \multirow{2}{*}{$\begin{array}{l}\text { Method of integral assessment based on } \\
\text { normalized indicators }\end{array}$} & \multicolumn{2}{|c|}{ Method of weight coefficients } \\
\hline & in additive form & in a multiplicative form \\
\hline $\begin{array}{c}y_{i j}=\sqrt[n]{x_{i j 1} \times x_{i j n}}, \\
\text { where: } \\
y_{i j}-\text { the hazard factor of the } i \text {-th region of } \\
\text { the } j \text {-th bloc of hazard, } \\
x_{i j 1} \text { - the normalized value of the } j \text {-th in- } \\
\text { dex of the } i \text {-th region, } \\
n-\text { number of indicators in the block, } \\
A=\sqrt[k]{y_{i j 1} \times y_{i j k}}, A=\sqrt[k]{y_{i j 1} \times y_{i j k}}, \\
A-\text { aggregate indicator of the natural and } \\
\text { man-made hazard of the region by the } \\
\text { identified blocks, } \\
k-\text { number of blocks }\end{array}$ & $\begin{array}{c}Y_{j}=\sum_{1}^{k} \beta_{k} \cdot y_{k j}, \\
\text { where: } \\
y_{k j}-k \text {-th index of hazard in } \\
\text { the } j \text {-th region, } \\
\beta_{k}-\text { weight coefficient factor } \\
\text { at } \sum_{k} \beta_{k}=1\end{array}$ & $\begin{array}{c}I_{j}^{M}=\prod_{j-1}^{m_{i}}\left(z_{i j}\right)^{\beta_{i j}} \\
\text { where: } \\
z_{i j} \text { - normalized value of } j \text {-th } \\
\text { ecological indicator; } \beta_{i j}- \\
\text { normalized value of } j \text {-th eco- } \\
\text { logical indicator; } \\
m-\text { number of indicators }\end{array}$ \\
\hline
\end{tabular}

On the other hand, the choice of some environmental factors and ignoring others, significantly affects the final assessments and ranges of territories. Thus, according to the methodology [7], the ecological risk for disturbing the sustainability of natural ecosystems by radiation contamination was also taken into account in order to determine the ecological danger in the regions of Ukraine. It is shown that among all regions of Ukraine in Donetsk and Zhytomyr regions are in the most dangerous condition. This is due to the high level of radiation contamination caused by the Chernobyl accident. At the same time, a comprehensive assessment according to the [5, 6], without taking into account radiation exposure, allowed to bring Zhytomyr region to the rank of areas with an average level of environmental safety.

The aim of the article is to identify priorities and to analyze the methodological bases of evaluation and differentiation of territorial units according to the levels of environmental hazard.

Results and discussion. The development of preventive priority safety measures should be based on a detailed analysis of the territorial distribution of sources of potential hazards. The determination of the levels of environmental hazard (or, conversely, safety) can occur according to different criteria, such as the ecological state, the regime of nature management, resource potential, sanitary-hygienic, medical-biological, landscape, hydrological and other factors. Criterion ranking areas is important not only for the principles and methodology of the selection process hazard levels. No less important for the characteristics of the properties of territorial groups on the basis of algorithms for assigning those or other parameters to a particular rank.

The authors of the current article have systematized the main approaches to ranking the regions of Ukraine on the levels of environmental hazards (EH), or its associated environmental risks, which are summarized in Table 2. The advantages and disadvantages of existing methods of distribution of all regions of Ukraine are presented in [8]. From Table 2 it follows that mainly all approaches differ in the number of differentiation groups and intervals of numerical values. The justification of these parameters by analytical methods is carried out only in works [4, 6]. As a result, one area under different classifications can be characterized by different levels of hazards, from moderate to critical, even using close indicators of determining the rank of hazard of the region, but based on risk analysis and integral indicator.

As an example, Zhytomyr region, as well as Kyiv, Lviv, Vinnytsia and others can be mentioned. Areas with high level of hazards for practically all classifications include areas with developed industrial potential and cities with high population density. An example is a group of regions, which includes Odessa, Kharkiv, Dniprovsky, Zaporozhye regions. 
Analysis of approaches to ranking the regions of Ukraine on the levels of environmental hazard

\begin{tabular}{|c|c|c|c|}
\hline № & $\begin{array}{l}\text { Factor and methodology of } \\
\text { differentiation }\end{array}$ & $\begin{array}{l}\text { Numerous intervals of } \\
\text { hazard levels }\end{array}$ & Regions \\
\hline \multirow{5}{*}{1} & \multirow{5}{*}{$\begin{array}{l}\text { Comprehensive evaluation of } \\
\text { levels of natural and man-made } \\
\text { safety of regions on the basis of } \\
\text { aggregated indicator [5] }\end{array}$} & $\begin{array}{l}\text { The high level is more } \\
\text { than } 0.141\end{array}$ & $\begin{array}{c}\text { Dniprovska, Odessa, Zaporozhia, Nikolaev, } \\
\text { Donetsk }\end{array}$ \\
\hline & & $\begin{array}{c}\text { Increased level is } \\
0.119 \ldots 0.141\end{array}$ & Rivne, Khmelnytsky, Kharkiv, Lugansk \\
\hline & & $\begin{array}{c}\text { Average level is } \\
0.096 \ldots 0.119\end{array}$ & Poltava, Ivano-Frankivsk, Kherson \\
\hline & & $\begin{array}{c}\text { Moderate level is } \\
0.058 \ldots 0.096 \\
\end{array}$ & $\begin{array}{c}\text { Kiev, Chernigov, Ternopil, Chernivtsi } \\
\text { Cherkasy, Vinnitsa, } \\
\end{array}$ \\
\hline & & Low level is up to 0.0574 & Volyn, Zhytomyr, Transcarpathian, Lviv, Kyiv \\
\hline \multirow{3}{*}{2} & \multirow{3}{*}{$\begin{array}{l}\text { Based on environmental risk } \\
\text { assessment. } \\
\text { Regions of Ukraine are } \\
\text { differentiated on the basis of the } \\
\text { calculated total risks of } \\
\text { deterioration of the air, soil, } \\
\text { surface waters and the level } \\
\text { of radiation pollution [8] }\end{array}$} & $\begin{array}{l}\text { Very high }(1) \\
\text { High is } 0.64 \ldots 0.80 \text {, }\end{array}$ & $\begin{array}{l}\text { Zhytomyr (0.683) } \\
\text { Donetsk (0.648) }\end{array}$ \\
\hline & & $\begin{array}{l}\text { Considerable is } \\
0.38 \ldots 0.63\end{array}$ & $\begin{array}{c}\text { Dniprovskaya (0.462), Zaporozhia (0.529), } \\
\text { Lugansk (0.374), Odessa (0.446), Kharkiv } \\
\text { (0.374), Kherson (0.563), }\end{array}$ \\
\hline & & $\begin{array}{c}\text { Increased } \\
0.21 \ldots 0.37\end{array}$ & $\begin{array}{c}\text { Vinnytsa (0.362), Transcarpathian (0.227), } \\
\text { Ivano-Frankivsk (0.331), Poltava (0.261), } \\
\text { Ternopil (0.332) }\end{array}$ \\
\hline \multirow{6}{*}{3} & \multirow{6}{*}{$\begin{array}{l}\text { By the level of assessments of } \\
\text { complex risk for the EH of re- } \\
\text { gions of Ukraine. } \\
\text { Assessed risks from loss of life or } \\
\text { health of the population from } \\
\text { emergency situations (ES); from } \\
\text { loss and damage to economic } \\
\text { objects of the region as a result of } \\
\text { the ES; the risk of loss or damage } \\
\text { to the environment of the region } \\
\text { as a result of ES [6] }\end{array}$} & $\begin{array}{c}\text { Small } \\
0.076 \ldots 0.130 \\
\end{array}$ & $\begin{array}{c}\text { Nikolaev (0.076), Kirovograd (0.121), Rivne } \\
(0.121)\end{array}$ \\
\hline & & $\begin{array}{c}\text { Moderate } \\
0.131 \ldots 0.184\end{array}$ & $\begin{array}{c}\text { Kherson 0.149), Odessa (0.171), Kharkiv } \\
\text { (0.176), Transcarpathian }\end{array}$ \\
\hline & & $\begin{array}{c}\text { Average } \\
0.185 \ldots 0.238 \\
\end{array}$ & $\begin{array}{c}\text { Volyn (0.189), Zaporozhye (0.190), Poltava } \\
(0.220) \text {, Dniprovska (0.248) }\end{array}$ \\
\hline & & $\begin{array}{c}\text { Increased } \\
0.239 \ldots 0.292 \\
\end{array}$ & $\begin{array}{l}\text { Khmelnytsky (0.246), Vinnytsia (0.248), Kyiv } \\
(0.254) \text {, Ivano-Frankivsk (0.292) }\end{array}$ \\
\hline & & $\begin{array}{c}\text { Hight } \\
0.293 \ldots 0.347 \\
\end{array}$ & $\begin{array}{c}\text { Chernihiv (0.347), Cherkasy (0.330), Ternopil } \\
(0.314) \text {, Lugansk (0.312), Lviv (0.298) }\end{array}$ \\
\hline & & $\begin{array}{c}\text { Critical } \\
0.348 \ldots 0.729 \\
\end{array}$ & Donetsk (0.727) \\
\hline \multirow{6}{*}{4} & \multirow{6}{*}{$\begin{array}{l}\text { By integral indicator of ecological } \\
\text { safety (ES) with application of } \\
\text { weight coefficients. Included are } \\
\text { indicators of emissions into the } \\
\text { air, waste generation, } \\
\text { reproduction of forests, mortality } \\
\text { of the population, material } \\
\text { damage from the ES of different } \\
\text { origins, individual risk of death } \\
\text { from the ES [4] }\end{array}$} & $\begin{array}{l}\text { The lowest } \\
0.563 \ldots 0.498\end{array}$ & Dniprovskaya (0.563), Lugansk (0.513) \\
\hline & & $\begin{array}{c}\text { Low } \\
0.498 \ldots 0.431\end{array}$ & Transcarpathian (0.433) \\
\hline & & $\begin{array}{c}\text { Average } \\
0.431 \ldots 0.364 \\
\end{array}$ & $\begin{array}{c}\text { Zhytomyr (0.405), Donetsk (0.373), Ivano- } \\
\text { Frankivsk }\end{array}$ \\
\hline & & $\begin{array}{c}\text { Moderate } \\
0.364 \ldots 0.297 \\
\end{array}$ & $\begin{array}{c}\text { Nikolaev (0.358), Kiev (0.348), Zaporozhye } \\
(0.328)\end{array}$ \\
\hline & & $\begin{array}{c}\text { Essential } \\
0.297 \ldots 0.230\end{array}$ & $\begin{array}{c}\text { Kharkiv (0.240), Vinnytsia (0.282), Rivne } \\
\text { (0.283), Volyn }(0.292)\end{array}$ \\
\hline & & $\begin{array}{l}\text { The hightest } \\
0.230 \ldots 0.110\end{array}$ & Lviv (0.163), Ternopil (208), Odessa (0.217) \\
\hline
\end{tabular}

The possibility of natural accidents and processes that threaten the critical transport infrastructure of the regions (karst, landslides, flooding) do not affect the overall security of such areas as IvanoFrankivsk, Kherson, and Volyn regions, but they determine the high level of risks in Chernihiv, Ternopil, Lviv regions. On the contrary, according to index estimates, the last group of regions has moderate hazards. Areas characterized by critical levels of hazards practically all approaches (Donetsk, 
Luhansk, Zaporizhzhya) are characterized, above all, by the outdated industrial sector, depreciated infrastructure of large cities against the backdrop of high density of their population.

Limitations and disadvantages of assessments of ecological hazard levels of regions, which are given in Table 2, can be summarized as follows:

1. Almost all approaches are based on the principles of linearity and unidirectional action.

2. The results of assessments depend on the nature of the factors taken into account.

3. As a rule, the vector nature of environmental factors is not considered, and when they are summed up, the principle of the compilation of vectors is not taken into account. The vector nature of the factors of influence the authors of the article understand more complexly than the direction within the defined territory or space. The vector of action may be caused by the gradient of the value of the factor indicator, or the selectivity of its action on a separate group of people or other living organisms, on certain types of objects (natural or man-made), or landscapes, etc.

4. The possible synergistic effects are not taken into account in the interaction of various factors, which can lead not only to the strengthening of the effects and inadequate exacerbation of the environmental situation, as well as to the branched consequences of the "domino" principle.

5. Indirect impacts, data on transboundary impacts, and the spread of danger on adjacent territories are not taken into account.

Based on the analysis of the above-described approaches, we proposed a generalization of the ranking of regions of Ukraine (Table 3) on the levels of hazards. To the scheme, we included regional distribution data based on qualitative estimates conducted without calculating of numerical values of integral indicators or risk assessments. For example, the authors analysed method of accounting of value of man-made and natural hazards, and the method of establishing levels of resource and environmental safety of the region as derivatives degree of secondary raw materials and recycling waste energy $[8,9]$. Differentiation of regions corresponding to levels of hazard from the first (1) low hazard level to the highest level of environmental risk $(5,6)$. Each method that was used in the data analysis is marked with a separate tint of gray (or color), and its intensity corresponds to the degree of hazard of the ecological state of the region. It should be noted that the highest level of environmental safety corresponds to the lowest level of hazard, and vice versa.

Data in Table 3 demonstrate a significant difference in the environmental risk categories of areas if they are determined by different approaches and methods of assessment. Such a mosaic of the ranks of regions can not be the result of only different methods of calculating the index value or risk. The introduction of extended groups of indicators (for example, indicators of resource-ecological safety or indicators of radiation pollution of the components of the environment) should clarify the environmental status of the territory, rather than radically change the calculated level of hazards.

The imperfection of the methodological basis for determining the levels of environmental hazard is caused by a number of factors.

First, the difference between the regions is offset by the ratio between urban and rural areas, affecting the character of the placing the industry, potentially dangerous objects, critical infrastructure and so on. This complicates the consideration of transboundary impacts, synergies of interregional interactions and determination of the vector nature of the impact of man-made factors. It also follows that integral indicators equate the effects of threats to different types of territories and weight coefficients (by expert judgment or otherwise) (Table 1) are not able to show the territorial aspects of a particular threat. Thus, the contribution of urban areas to the volume of emissions into the air, on the one hand, differs significantly from the contribution of countryside. Moreover, this difference manifests itself differently in different regions. On the contrary, other groups of indicators that take into account, for example, the reproduction of forests, the condition of agricultural lands, mainly characterize the status of rural areas.

The authors of the article believe that in order to more adequately compare the safety ratings of the regions, it is advisable to enter the index of "urbogenicity" of the region. Such an index should include the indicators of the total number of cities in the oblast, their distribution by population and density, the proportion between urban and rural population, the territorial division between large and small cities, between 
cities and villages. The index of urbogenicity can also take into account the nature of the placement of cities and specific objects in the region, so it would be appropriate to use the data of geographic information systems. Modern GIS technologies provide the opportunity to receive information on the current ecological state of the territory and to predict the dynamics of its changes. Thus, the index urbogenicity ensures consideration of the contribution of urban systems in general state of area environmental hazard, and also details the character of urbohenno-man-made impacts and associated risks.

Table 3

Scheme of ranking of regions of Ukraine on the levels of environmental hazard

\begin{tabular}{|c|c|c|c|c|c|c|c|c|}
\hline \multirow{2}{*}{ № } & \multirow{2}{*}{ Region } & \multicolumn{7}{|c|}{ Method number / number of levels of hazards } \\
\hline & & $1[8] / 5$ & $2[5] / 5$ & $3[7] / 5$ & $4[9] / 4$ & $5[6] / 6$ & $6[4] / 6$ & $7[3] / 4$ \\
\hline 1 & Vinnitsa & 4 & 2 & 2 & 2 & 4 & 2 & 1 \\
\hline 2 & Volyn & 1 & 1 & 2 & 2 & 3 & 2 & 2 \\
\hline 3 & Dniprovska & 5 & 5 & 3 & 3 & 3 & 6 & 4 \\
\hline 4 & Donetsk & 5 & 5 & 4 & 3 & 6 & 4 & 4 \\
\hline 5 & Zhytomyr & 1 & 1 & 5 & 3 & 2 & 4 & 1 \\
\hline 6 & Transcarpathian & 1 & 1 & 2 & 2 & 2 & 5 & 1 \\
\hline 7 & Zaporozhye & 4 & 5 & 3 & 4 & 3 & 3 & 2 \\
\hline 8 & Ivano-Frankivsk & 1 & 3 & 2 & 3 & 4 & 4 & 2 \\
\hline 9 & Kirovograd & 3 & 2 & 3 & 3 & 1 & 4 & 1 \\
\hline 10 & Kievskaya & 4 & 2 & 3 & 3 & 4 & 3 & 3 \\
\hline 11 & Lugansk & 5 & 4 & 3 & 4 & 5 & 6 & 4 \\
\hline 12 & Lviv & 3 & 1 & 2 & 2 & 5 & 1 & 2 \\
\hline 13 & Nikolaev & 2 & 5 & 3 & 2 & 1 & 3 & 1 \\
\hline 14 & Odessa & 2 & 5 & 3 & 3 & 2 & 1 & 2 \\
\hline 15 & Poltava & 3 & 3 & 2 & 2 & 3 & 2 & 2 \\
\hline 16 & Rivne & 2 & 4 & 3 & 2 & 1 & 2 & 1 \\
\hline 17 & Sumy & 4 & 2 & 2 & 3 & 2 & 3 & 1 \\
\hline 18 & Ternopil & 2 & 2 & 2 & 3 & 5 & 1 & 1 \\
\hline 19 & Kharkiv & 3 & 4 & 3 & 3 & 2 & 2 & 2 \\
\hline 20 & Kherson & 3 & 3 & 3 & 2 & 2 & 4 & 1 \\
\hline 21 & Khmelnitsky & 2 & 4 & 3 & 2 & 4 & 2 & 1 \\
\hline 22 & Cherkassy & 3 & 2 & 3 & 3 & 5 & 2 & 1 \\
\hline 23 & Chernivtsi & 2 & 2 & 3 & 2 & 2 & 3 & 1 \\
\hline 24 & Chernihiv & 2 & 2 & 3 & 3 & 5 & 3 & 1 \\
\hline 25 & Crimea & - & - & - & - & 4 & 1 & 2 \\
\hline
\end{tabular}

Table 3 shows that almost every region is characterized by a spectrum of level of hazards (for example, Vinnitsa - from 1 to 4, Transcarpathian, Zhytomyr, Lviv, Ternopil - from 1 to 5). Such a situation may be the result of a reassessment of the impact indicators on environment calculated on the basis of statistical data, and an underestimation of sustainable factors and the possibility of dynamic changes in the geosystems of a particular territory. As an additional approach, it would be appropriate to use advanced data on the state of the natural components that compensate for the effects of different genesis and determine the ecological safety of the region in terms of maintaining a sustainable equilibrium of territorial geosystems. Thus, to characterize the sustainability of urban ecosystems can use the evaluation of the state of urban green areas. Green plants not only themselves are compensators of harmful effects, but also indirectly reflect the state of soil, humidity, climate, relief, level of mancaused load and other factors [10].

Data summarized in Table 2 and Table 3, also show contradictions in the methods for allocating the number of hazard groups and the size of the corresponding ranges. Both complex indicators as well as risk assessments vary extremely unevenly by region, and the distribution of their numerical values for different categories of hazards, as a rule, is subjective. Only in works $[4,6]$ the number of groups of differentiation 
was determined by the Sterjes formula, but with equal ranges of values of integral indicators and risk assessments. As a result, according to the numerical values of the indicators, the difference between regions of one rank may be greater than the difference between regions belonging to different ranks. For example, Kherson (integral indicator of ecological hazard - 0.406) and Nikolaev (0.358) regions are differentiated into different groups of environmental safety, and the difference between the values of indicators is 0.048 . Odessa (0.217) and Lviv (0.163) regions are classified as one, the lowest level of danger, but the difference between the indicators is greater, and is 0.054 . There are many examples of such contradictions.

An alternative method of differentiation of territorial grouping is cluster analysis as a modern way of data systematization, designed to structure and evaluate a large amount of different data. The cluster method allows simultaneously to identify both the homogeneity of the functional properties of the members of the same cluster, and the differences that divide the clusters among themselves. Examples of the application of the cluster method in environmental studies and the ability to take into account such functions that are hidden in other methods of statistical analysis, presented by us in the work [11]. So, one can expect the grouping of Ukrainian regions in homogeneous clusters according to the close values of the corresponding indicators.

Conclusions. Formation of the rating of territorial units according to the estimations of the ecological situation and levels of ecological safety most closely corresponds to the system conception of the functional-territorial approach to the management of ecological safety and is the basis for implementation of safety measures. The analysis of the ranking methods of the regions of Ukraine revealed a significant discrepancy in the results of assessments both by index methods and by methods of risk indicators. This prevents the principle of consistency and reduces the effectiveness of environmental safety at the state level.

Authors proposed the ways of improving the methodological foundations for determining the levels of environmental hazard through the introduction of the index of "ergogeny" of the region and taking into account the restorative possibilities of natural landscapes as a basis for stabilizing the ecological balance and compensating of negative urbohenno-man-made influences. A cluster method was proposed for the differentiation of regions. This method can take into account the complexity of geosystems by processing large amounts of data, adaptive behavior of components, uniformity of environmental situations in regions that are members of the same group.

\section{Література}

1. Wilson J., Tyedmers P., Pelot R. Contrasting and comparing sustainable development indicator metrics. Ecological Indicators. 2007. № 7. P. 299-314. URL: https://www.researchgate.net/publication/ 223804576_Contrasting_and_comparing_sustainable_development_indicator_metrics. (Last accessed: 24.11.2017). (дата звернення).

2. Варламов С.М., Толстих Я.О. Аналіз формування та використання еколого-економічних показників та індикаторів для оцінки сталого розвитку регіону. Системи обробки інформацї. 2011. Вип. 3(93). С. 165-168. URL: http://nbuv.gov.ua/UJRN/soi_2011_3_40. (дата звернення 12.11.2017).

3. Качинський А. Б. Екологічна безпека України: системний аналіз перспектив покращення: монографія. Київ: НІСД. 2001. 312 с. URL: http://www.niss.gov.ua/book/Kachin/index.htm_(дата звернення 26.10.2017).

4. Іванюта С.П., Качинський А.Б. Екологічна безпека регіонів України: порівняльні оцінки. Стратегічні пріоритети. Київ: НІСД, 2013. № 3(28). С.157-164.

5. Екологічна і природно-техногенна безпека України в регіональному вимірі. / за наук. ред. М.А. Хвесика. Київ: ДУ ІЕПРС НАН України, 2014. 340 с.

6. Іванюта С.П. Оцінка економічного ризику природних і техногенних надзвичайних ситуацій в Україні. Екологічна безпека та природокористування: зб. наук. пращь. Київ. нац. ун-т буд-ва і архіт., НАН України, Ін-т телекомунікацій і глобал. інформ. простору. Київ, 2012. Вип. 11. С. 30-42. URL: http://dspace.nbuv.gov.ua/handle/123456789/57551_(дата звернення 26.10.2017).

7. Рибалова О.В., Белан С.В., Варивода С.О. Визначення рівня екологічної небезпеки в регіонах України на основі оцінки екологічного ризику. Проблеми надзвичайних ситуацій. Збірник наукових праць. Вип. 12. 2010. С. 132-143. URL: http://edu-mns.org.ua/nmc/94/pns12.pdf (дата звернення 26.10.2017). 
8. Васютинська К.А., Барбашев С.В. Підходи до визначення рівнів екологічної небезпеки регіонів. Екологічна безпека: проблеми і шляхи вирішення: зб. наук. статей XIII Міжнар. наук.-практ. конф. Харків: Райдер, 2017. С. 59-64.

9. Самойлік М.С. Ресурсно-екологічна безпека регіону: монографія. Полтава: Сімон, 2014. 317 с.

10. Vasiutynska K., Makarov A. Environmental dimensions of forming green zone in Odessa city. Сучасні наукові дослідження та розробки: теоретична ичінність та практичні результати. Міжн. наук.практ. конф. Братислава, 2016. т.4. С. 29-30.

11. Васютинська К.А., Барбашев С.В. Визначення рівнів екологічної безпеки міської території за допомогою кластерного методу. Екологічна безпека: проблеми і шляхи вирішення: зб. наук. статей XIII Міжнародної науко-практичної конференції. Харків: Райдер, 2017. С.54-58.

\section{Referenses}

1. Wilson, J., Tyedmers, P., \& Pelot, R. (2007). Contrasting and comparing sustainable development indicator metrics. Ecological Indicators, 7, 299-314. Available at: https://www.researchgate.net/ publication/223804576_Contrasting_and_comparing_sustainable_development_indicator_metrics.

2. Varlamov, Ie.M., \& Tolstykh, Ia.O. (2011). Analysis of the formation and use of environmentaleconomic indicators and indicators for assessing sustainable development in the region. Information Processing System, 3 (93), 165-168. Available at: http://nbuv.gov.ua/UJRN/soi_2011_3_40.

3. Kachynskyi, A.B. (2001). Ecological safety of Ukraine: system analysis of prospects for improvement: monograph. The National Institute for Strategic Studies, 312. Available at: http://www.niss.gov.ua/ book/Kachin/index.htm.

4. Ivaniuta, S.P., \& Kachynskyi, A.B. (2013). Environmental safety of the regions of Ukraine: comparative assessments. Strategic Priority Magazine. Kyiv: The National Institute for Strategic Studies, 3 (28), 157-164.

5. Obykhod, H.O., Khvesyk, M.A., \& Stepanenko, A.V., et al. (2014). Ecological and environmentalindustrial security of Ukraine in regional dimension. M.A. Hvesik (Ed.) Kyiv: State Institution "Institute of Environmental Economics and Sustainable Development of the NAS of Ukraine”.

6. Ivaniuta, S.P. (2012). Assessment of the economic risk of natural and man-made emergencies in Ukraine. Enviromental and Natural Resources. Kyiv. 11, 30-42. Available at: http://dspace.nbuv.gov. ua/handle/123456789/57551

7. Rybalova, O.V., Belan, S.V., \& Varyvoda, Ie.O. (2010). The determination of environmental danger level in Ukrainian regions on the basis of environmental risks assessment. Compilation of scientific works problems of tmergencies. 12, 132-143. Available at: http://edu-mns.org.ua/nmc/94/pns12.pdf.

8. Vasiutynska, K.A., \& Barbashev, S.V. (2017). Approaches to determination of levels of ecological danger of regions. Environmental safety: problems and solutions: XIII International science-practice conference. (Kharkiv, UKRNDIEP, 11 - 15 veresnia) (pp. 59 - 64). Kharkiv: Raider.

9. Samoilik, M.S. (2014). Resource and environmental safety of the region: monograph. Poltava: Simon.

10. Vasiutynska, K., \& Makarov, A. (2016). Environmental dimensions of forming green zone in Odessa city. Contemporary research and development: theoretical value and practical results. (15-18 March), 4, (pp. 29-30). Bratyslava.

11. Vasiutynska, K.A., \& Barbashev, S.V. (2017). Determination of levels of environmental safety of urban areas by cluster method. Environmental safety: problems and solutions: XIII International Scientific and Practical Conference. (11-15 September) (pp. 54 - 58) Kharkov: Ryder. 